Pak. j. sci. ind. res. Ser. A: phys. sci. 201356 (2) 107-121

\title{
Hydrochemical Characterization and Quality Evaluation of Groundwater in Parts of the Basement Complex Area of Ekiti, Southwestern Nigeria
}

\author{
Talabi Abel Ojo ${ }^{\text {a* }}$ and Tijani Moshood Niyib \\ ${ }^{a}$ Department of Geology, Ekiti State University, Ado-Ekiti, Nigeria \\ ${ }^{\mathrm{b}}$ Department of Geology, University of Ibadan, Ibadan, Nigeria
}

(received August 8, 2011; revised March 29, 2012; accepted April 25, 2012)

\begin{abstract}
Well water (88 samples) were collected across various bedrock units in the basement terrain of Ekiti area, Southwestern Nigeria. They were subjected to in-situ physico-chemical measurement and hydrochemical analyses using ICP-OES and ion-chromatography methods for cations and anions, respectively. To understand the water quality and utilisation aspects of groundwater, chemical indices like sodium $\%$, sodium adsorption ratio (SAR), Wilcox diagram and salinity diagram were constructed based on the analytical results. The results show $\mathrm{pH}$ values ranging between 6.0-7.8 and total hardness (TH) 3.2-508.7 mg/L. Major cations concentrations were in the order of $\mathrm{Ca}^{2+}>\mathrm{K}^{+}>\mathrm{Na}^{+}>\mathrm{Mg}^{2+}$ with average values of $28.5,26.8,24.2$ and $7.9 \mathrm{mg} / \mathrm{L}$, respectively while that of the anions were $\mathrm{HCO}_{3}{ }^{-}>\mathrm{Cl}^{-}>\mathrm{SO}_{4}{ }^{2-}$ $>\mathrm{NO}_{3}{ }^{-}$with average values of $118.7,54.2,23.8$ and $0.92 \mathrm{mg} / \mathrm{L}$. The main hydrochemical facies being $\mathrm{Ca}-\mathrm{HCO}_{3}$ waters. The ionic orders of abundance varied in different rocks of the study area. These concentration trends show a low total dissolved solids $(130-1544 \mu \mathrm{S} / \mathrm{cm})$ indicating a low water-rock interaction due to low residence time which is an indication of $\mathrm{CO}_{2}$ dominated infiltration recharge with limited migratory history typical of the shallow basement terrain in the study area. Quality assessment revealed a potable groundwater system with chemical parameters within the acceptable limits of the WHO and SON drinking water standards with exception of $\mathrm{Fe}, \mathrm{Mn}$ and $\mathrm{Pb}$ in a couple of locations. Also, the estimated SAR alongside TDS revealed a shallow groundwater system suitable for irrigation purposes.
\end{abstract}

Keywords: basement, sodium adsorption ratio, salinity, water-rock interaction, irrigation

\section{Introduction}

Water quality assessment is an integral part of groundwater management. Water quality is a term used to describe the chemical, physical and biological characteristics of water, usually with respect to its suitability for a particular purpose. Assessment of the occurrence of chemicals that can harm water quality such as nutrients and pesticides in water sources, require recognition of complicated interconnections among surface water and ground water, atmospheric contributions, natural landscape features, human activities, and aquatic health.

Olayinka et al. (1999) suggested that water quality is subjective and as such depends on its use. Therefore, water quality standards differ depending on various uses including domestic (drinking), agriculture/irrigation and industrial applications. The water quality may yield information about the environments through which the water has circulated (Raju, 2007).

Groundwater usage in the crystalline basement terrain of Ekiti area, Southwestern Nigeria is increasing as a *Author for correspondence; E-mail: soar_abel@yahoo.com result of population growth and agricultural activities. Going by the 1991 census, the population of the area was 1.65 million while in 2001 it was 2.05 million. This represents about $2.44 \%$ growth rate per annum with a current projected population of about 2.55 million that has led to the expansion of large areas of unplanned sub-standard housing especially in the major towns of the study area. In most of these areas public water supply by government is not available and as such residents of these areas usually use groundwater as a source of inexpensive high quality domestic water supply. The uncontrolled expansion of this kind of housing, together with increasing sewage and effluent leakage, indiscriminate waste disposal and uncontrolled commercial activities has led to increasing pollution and deterioration of groundwater quality which may probably result in public health problems. The uncontrolled application of fertilizer and pesticides to sustain agriculture that employs over $80 \%$ of the workforce in the study area could contribute to groundwater contamination in addition to possible contamination arising from domestic waste, sanitary sewage as well as a wide 
variety of dissolved and suspended contaminants. This trend warrants an understanding of the hydrogeochemistry of the groundwater system, providing the fact that both agriculture and domestic water supply rely on the shallow groundwater system of the study area.

Groundwater has particular importance in the crystalline basement terrain of Ekiti area where most people rely on a combination of hand-dug wells and public boreholes for their drinking water supply. Although, groundwater use is generally less visible than surface water supplies, but surface water is more prone to contamination from anthropogenic activity and in many situations could not be extended to the rural populace where potable water is inadequate due to high cost distribution network. On the other hand, groundwater could be made available in residential areas apart from the fact that it increasingly provides the main source of agricultural irrigation in the study area as well as vital safety net for the dry season food security when most of the streams and rivers have dried off.

Water quality analysis is one of the most important aspects in groundwater studies. The hydrochemical study reveals the quality of water that is suitable for domestic, agriculture and industrial purposes. Also, changes in groundwater quality due to water-rock interaction or any type of anthropogenic influence can be understood through such type of study (Sadashivaiah et al., 2008). The definition of water quality depends much on the desired use of water. Therefore, different uses require different criteria of water quality as well as standard methods for reporting and comparing results of water analysis (Babiker et al., 2007). Additionally, the chemical composition of groundwater is dictated by a combination of factors such as lithogenic input of metals through water-rock interaction, anthropogenic activities and more recently the impacts of climatic variability (Berner and Berner, 1987).

Apart from the above highlighted issues, in previous research was carried out in Southwestern Nigeria on groundwater potential zonation, chemical quality and geophysical and geo-electrical characteristics of shallow groundwater by Talabi and Tijani (2011), Tijani et al. (2010), Omotoyinbo and Okafor (2008), Oyinloye and Ademilua (2005), Bolarinwa and Elueze (2005), Elueze et al. (2004) and Ehinola (2002).

Location and geological setting of the study area. The study area (Ekiti area) is located between latitudes $7^{\circ} 25^{\prime}-7^{\circ} 52^{\prime} \mathrm{N}$ North of the Equator and longitudes $4^{\circ} 48^{\prime}-5^{\circ} 30^{\prime} \mathrm{E}$ east of Greenwich Meridian covering an area of about $4,344 \mathrm{~km}^{2}$ (Fig.1). The area is characterized by alternating wet and dry season. The wet season usually lasts from April to October and is dominated by heavy rainfall $(1500 \mathrm{~mm})$ while the dry season covers the period from November to March every year with temperature ranging from $25-30{ }^{\circ} \mathrm{C}$. The topography is generally undulating with most area lying above $250 \mathrm{~m}$ above sea level. The landscape is characterized by old plains, broken by steep sided outcrop dome rocks (Inselbergs) that may occur singularly or in crops of ridges. Such outcrops exist mainly in form of rugged hills at Ado-Ekiti (central part of the study area) and Ikere-Ekiti in the southern part. The study area is underlain by Precambrian crystalline rocks mostly of igneous-metamorphic origin with ages greater than $300 \mathrm{Ma}$ to $450 \mathrm{Ma}$ (Matheis, 1987). Prominent rock units include granite gneiss, migmatites, schist/ quartz schist, porphyritic granite, fine-medium grained granite and charnockite.

The migmatites are predominant in the study area covering over $50 \%$ (Fig. 2).

The rock exposures occur as highly denuded hills of essentially fine-medium textures with closely spaced alternating bands of leucocratic and melanocratic minerals. They are characteristically low lying, fine textured, and conspicuously foliated with abundance of platy biotite minerals sandwiched into zones that are markedly distinguishable from the light coloured quartzo-feldspartic portions. The granite and the charnockite occur as intrusive bodies into the pre-existing migmatite rocks. Their textures range from fine to medium grain and in some cases coarse-porphyritic. Quartzite occurs as ridge of steeply dipping, massively bedded, fine-medium grained bodies while in some cases as quartz rubbles.

Hydrogeological setting of the study area. The hydrogeology of the area is controlled by climatic factors in addition to geology and structural features. The geological formations underlying an area and the structures determine the types of aquifer and their recharge process while climatic factors determines the amount and rate of recharge of the aquifer (Ademilua and Olorunfemi, 2000). The major surface waters in the study area are the rivers Ogbesse, Elemi, Obiba, Ureje, Ero, Osun, Ose and Oni with their tributaries forming a somewhat dendritic drainage pattern (Fig. 1). 
The volume of water in the rivers depends to a greater extent on the period of the seasons. During the rainy season, there is a great increase in flow volume in the rivers while there is complete absence of water in some of the rivers during dry season. In any basement rock area, groundwater occurs in the weathered mantle or in the joints and fractured systems of the unweathered rocks and in buried stream channels (Ako and Olorunfemi, 1989).

Surface water percolates down through the fractures starting the chemical weathering processes. However, it has been reported that the highest groundwater yield in the study area are located where thick overburden overlies fractured rocks. Groundwater supply in the study area is mainly from shallow hand dug wells and shallow few boreholes. Two major aquifer units have been identified: the weathered and fractured bedrock units (Ademilua and Olorunfemi, 2000).

Generally, records of dug wells in the area indicate depths from 23.4 to $92.0 \mathrm{~m}$, static water levels from 1.0 to $21.0 \mathrm{~m}$ and yields in the range of $8.64-354.24 \mathrm{~m}^{3} /$ day (Talabi and Tijani, 2011). However, based on rock types, the depth of the dug wells vary from 23.4 to $80.0 \mathrm{~m}$ in the migmatite rocks, 26.0 to $92.0 \mathrm{~m}$ in the granites/granite

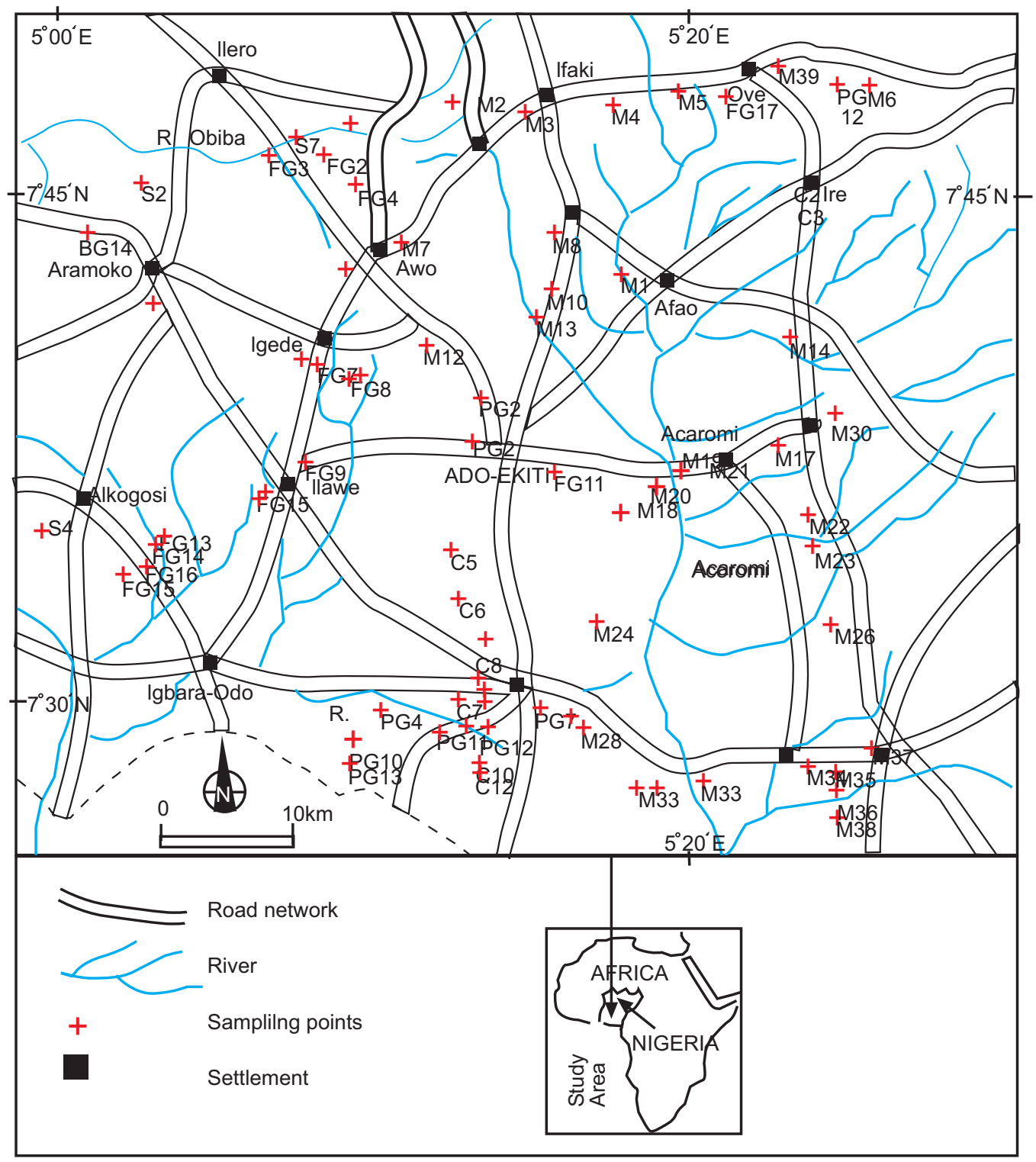

Fig. 1. Location map of the study area. 


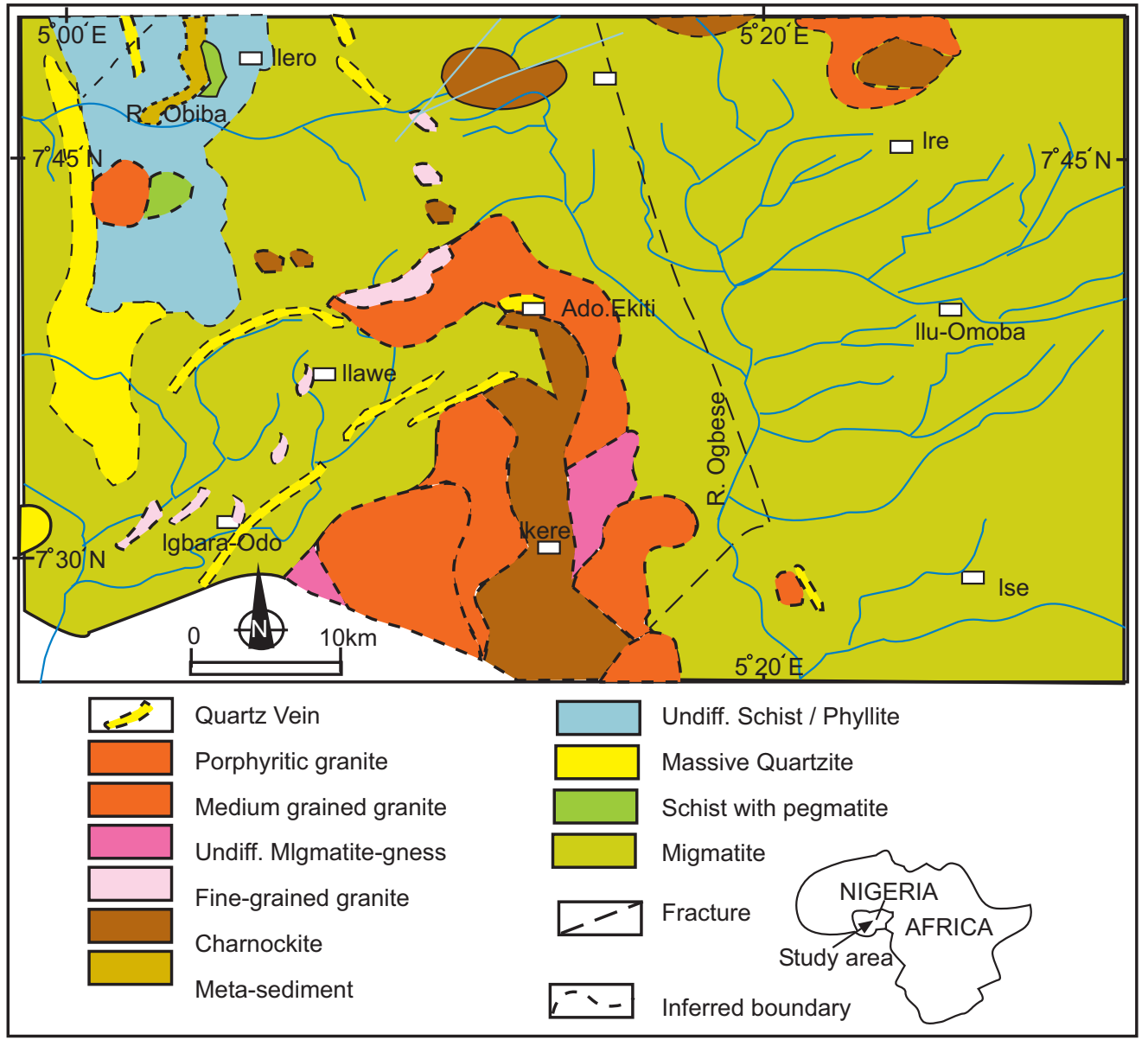

Fig. 2. Geological map of the study area.

gneisses and from 23.4 to $80 \mathrm{~m}$ in the quartzite/quartzschist rocks. The static water level ranges from 1.3 to $21.0 \mathrm{~m}, 1.0$ to $18.0 \mathrm{~m}$ and 2.0 to $14.4 \mathrm{~m}$ in the migmatites, granites/granite-gneisses and quartzite/quartzschist rocks, respectively. Dug wells yields are highly variable and lie in the range of 8.64-354.24 $\mathrm{m}^{3} / \mathrm{d}$ in the migmatites. In the granites/granite-gneisses and the quartzite/quartz-schist, wells yields are within 8.64$175.39 \mathrm{~m}^{3} / \mathrm{d}$ and $43.2-304.99 \mathrm{~m}^{3} / \mathrm{d}$, respectively. Thus, the groundwater in the study area is tapped at shallow depths for domestic and agricultural purposes through hand-dug wells that terminate in the weathered crystalline rocks and if deep enough could sustain the dry season.

The objective of the present study was to assess groundwater chemical composition based on rock types and its suitability for different uses (i.e. domestic, irrigation and drinking purposes) in the crystalline Basement area of Ekiti, Southwestern Nigeria.

\section{Materials and Methods}

Groundwater samples were obtained from 88 water wells spatially distributed over the study area in July, 2008 (Fig.1). The samples were collected in clean polythene bottles. Prior to collection, the polythene bottles were pre-cleaned by rinsing them in $10 \%$ nitric acid and subsequently cleaned with de-ionized water. Two sets of samples were taken from each well. The first set for cations/metals determination were acidified with concentrated nitric acid while the other set for anion analyses were left unacidified. Cation concentrations were analysed by ICP-OES method while anion analysis was by the ion-chromatography method. In situ measurements of temperature $\left({ }^{\circ} \mathrm{C}\right), \mathrm{EC}(\mu \mathrm{S} / \mathrm{cm})$ and $\mathrm{pH}$ were carried out using multiparameter portable meter (Testr ${ }^{\mathrm{Tm}} 35$ series). Field measurements of EC reflect the amount of total dissolved solids (TDS) in natural waters. The relationship between TDS and EC 
can be described by an equation; TDS $(\mathrm{mg} / \mathrm{L}) \approx \mathrm{EC}$ $(\mu \mathrm{S} / \mathrm{cm}) \times 0.75$ was employed in the present study. Measurement precision was checked by taking two replicates of the groundwater sample from each bedrock type including a blank in each batch. As part of data evaluation, the results were compared with local and international standards for drinking water (Standard Organisation of Nigeria (SON, 2007), World Health Organisation (WHO, 2004). Furthermore, statistical evaluation of the overall data was performed using Rockwork, 2004 v. 4.8.19, while chemical indices like percent sodium, sodium adsorption ratio (SAR) were calculated based on the analytical results.

\section{Results and Discussion}

Groundwater chemistry. Knowledge regarding the groundwater quality is important, as it is the main factor determining its suitability for drinking, domestic, agricultural and industrial utilization (Subramani et al., 2005). Table 1 shows summaries of the water chemistry while summaries based on different rock units in the study area compared with WHO (2004) and SON (2007) drinking water standards are presented in Table 2 . The results revealed that the analyzed groundwater samples were characterized by slight acidity to moderate alkalinity with $\mathrm{pH}$ values from 6.0 to 7.8. Electrical conductivity (EC) ranges from 30 to $1,544 \mu \mathrm{S} / \mathrm{cm}$ while TDS and TH range from 22.5 to $1158 \mathrm{mg} / \mathrm{L}$ and 3.2 to $508.7 \mathrm{mg} / \mathrm{L}$ (Table 1), respectively suggesting a low mineralized soft groundwater system with limited residence time and low water-rock interactions which could be responsible for the observed generally low concentration trends in different bedrock types (Table 2). However, 7 out of the total 88 groundwater samples within migmatite bedrock have their EC $>1000 \mu \mathrm{S} / \mathrm{cm}$. The relatively high TDS especially in the few sampling points close to dumpsite is an indication of contamination by leachates as one would have expected a low TDS of $<500 \mathrm{mg} / \mathrm{L}$ characteristic of uncontaminated freshwater in a typical basement complex setting.

In general, the concentration of the major cations was in the order $\mathrm{Ca}^{2+}>\mathrm{K}^{+}>\mathrm{Na}^{+}>\mathrm{Mg}^{2+}$ with average value of $28.5 \mathrm{mg} / \mathrm{L}, 26.5 \mathrm{mg} / \mathrm{L}, 24.5 \mathrm{mg} / \mathrm{L}$ and $7.9 \mathrm{mg} / \mathrm{L}$, respectively, while the order of major anions concentration was $\mathrm{HCO}_{3}{ }^{-}>\mathrm{SO}_{4}{ }^{2-}>\mathrm{Cl}^{-}>\mathrm{NO}_{3}{ }^{-}$with average value of $118.7 \mathrm{mg} / \mathrm{L}, 54.3 \mathrm{mg} / \mathrm{L}, 23.8 \mathrm{mg} / \mathrm{L}$ and $0.9 \mathrm{mg} / \mathrm{L}$, respectively. With respect to trace metals, the concentrations of $\mathrm{Co}(0.002-0.049 \mathrm{mg} / \mathrm{L}) ; \mathrm{Cu}(0.002$ -
$0.19 \mathrm{mg} / \mathrm{L}) ; \mathrm{Fe}(0.02-4.33 \mathrm{mg} / \mathrm{L}) ; \mathrm{Mn}(0.01-0.61 \mathrm{mg} / \mathrm{L})$; $\mathrm{Pb}(0.01-0.10 \mathrm{mg} / \mathrm{L})$ and $\mathrm{Zn}(0.005-1.72 \mathrm{mg} / \mathrm{L})$ were within the permissible limits of SON (2007) and WHO (2004) standards except in a few locations where Fe, $\mathrm{Mn}$ and $\mathrm{Pb}$ exceeded the standard values.

Iron and manganese often occur naturally together though the most common source of iron and manganese in groundwater of an area is man made, including sources from corrosion of metal in well casing, piping, pump parts, storage tanks or other objects of cast iron or steel that may be in contact with groundwater. Industrial effluent, acid-mine drainage, sewage and landfill leachates may also contribute iron and manganese to the groundwater of an area. However, in the study area, the sources of the iron and manganese can be attributed to weathering of iron and manganese bearing minerals and rocks, such as amphiboles, ferromagnesian micas and magnetite. Manganese or iron at concentrations above the drinking water guidelines may affect the taste or colour of well water. Although iron and manganese do not pose a health risk at levels normally found in drinking water, their presence indicate deteriorating groundwater quality and could necessitate well rehabilitation to forest all possible health problems that may arise from the deteriorating groundwater.

Table 1. Overall summary of chemical parameters in the study area

\begin{tabular}{|c|c|c|c|c|c|}
\hline Parameters & Min. & Max & Mean & Median & Std.Dev. \\
\hline Temp. & 23.9 & 29.9 & 26.69 & 26.7 & 0.96 \\
\hline $\mathrm{pH}$ & 6 & 7.8 & 6.16 & 6.1 & 0.63 \\
\hline $\mathrm{EC} \mu / \mathrm{cm}$ & 30 & 1544 & 433.7 & 291 & 349.9 \\
\hline TDS (mg/L) & 22.5 & 1158 & 325.27 & 218.25 & 262.42 \\
\hline $\mathrm{TH}$ & 3.22 & 508.74 & 193.78 & 77.55 & 86.62 \\
\hline $\mathrm{Ca} \mathrm{mg} / \mathrm{L}$ & 0.3 & 107 & 28.54 & 22.45 & 22.74 \\
\hline $\mathrm{Mg} \mathrm{mg/L}$ & 0.3 & 58.8 & 7.92 & 5 & 8.74 \\
\hline $\mathrm{Na} \mathrm{mg} / \mathrm{L}$ & 1.1 & 169 & 24.48 & 14.15 & 27.18 \\
\hline $\mathrm{K}$ mg/L & 0.3 & 143 & 26.54 & 9.8 & 33.72 \\
\hline $\mathrm{Fe} \mu \mathrm{g} / \mathrm{L}$ & 20 & 4330 & 370.45 & 105 & 716.61 \\
\hline $\mathrm{Mn} \mu \mathrm{g} / \mathrm{L}$ & 10 & 610 & 58.75 & 20 & 98.38 \\
\hline $\mathrm{Cu} \mu \mathrm{g} / \mathrm{L}$ & 2 & 186 & 8.55 & 2 & 22.08 \\
\hline $\mathrm{Pb} \mu \mathrm{g} / \mathrm{L}$ & 10 & 100 & 11.4 & 10 & 9.89 \\
\hline $\mathrm{Zn} \mu \mathrm{g} / \mathrm{L}$ & 5 & 1720 & 73.74 & 20 & 201 \\
\hline Co $\mu \mathrm{g} / \mathrm{L}$ & 2 & 49 & 3.27 & 2 & 5.88 \\
\hline $\mathrm{HCO}_{3} \mathrm{mg} / \mathrm{L}$ & 7.32 & 439.34 & 118.69 & 86.95 & 100.09 \\
\hline $\mathrm{SO}_{4} \mathrm{mg} / \mathrm{L}$ & 3.24 & 219.76 & 54.28 & 31.35 & 50.6 \\
\hline $\mathrm{Cl} \mathrm{mg/L}$ & 1.75 & 124.6 & 23.8 & 17.85 & 21.85 \\
\hline $\mathrm{NO}_{3} \mathrm{mg} / \mathrm{L}$ & 0.01 & 5.2 & 0.92 & 0.3 & 1.2 \\
\hline SAR & 0.15 & 4.98 & 1.04 & 0.69 & 0.87 \\
\hline MH & 2.34 & 49.59 & 21.31 & 20.28 & 9.72 \\
\hline
\end{tabular}

$\mathrm{SAR}=$ sodium adsorption ratio $; \mathrm{MH}=$ total hardness 
Table 2. Summary showing range of chemical parameters based on bedrock types compared with WHO and SON standard values

\begin{tabular}{|c|c|c|c|c|c|c|c|}
\hline Parameters & $\begin{array}{l}\text { Migmatite } \\
\mathrm{N}=37\end{array}$ & $\begin{array}{l}\text { Porphyritic } \\
\text { granite } \\
\mathrm{N}=14\end{array}$ & $\begin{array}{l}\text { F-M. grained } \\
\text { granite } \\
\mathrm{N}=17\end{array}$ & $\begin{array}{l}\text { Schist/ } \\
\text { quartz-schist } \\
\mathrm{N}=7\end{array}$ & $\begin{array}{l}\text { Charnockite } \\
\mathrm{N}=13\end{array}$ & $\begin{array}{l}\text { WHO } \\
\text { standards } \\
(2004)\end{array}$ & $\begin{array}{l}\text { SON } \\
\text { standards } \\
(2007)\end{array}$ \\
\hline Temp. ${ }^{\circ} \mathrm{C}$ & $24.6-28.5$ & $25.8-29.9$ & $23.9-27.1$ & $25.5-27.8$ & $25.4-29.1$ & - & - \\
\hline $\mathrm{pH}$ & $6.0-7.8$ & $6.1-6.7$ & $6.3-7.5$ & $6.2-7.2$ & $6.4-7.0$ & $6-9$ & $6.5-8.5$ \\
\hline $\mathrm{EC}(\mu \mathrm{S} / \mathrm{cm})$ & $30.0-1544.0$ & $90.0-775.0$ & $54.0-906.0$ & $133.0-1175.0$ & $31.2-215.1$ & 1500 & - \\
\hline TDS(mg/L) & $22.5-1158.0$ & $67.5-581.3$ & $40.5-679.5$ & $99.8-881.3$ & $46.5-510.8$ & 1000 & 500 \\
\hline $\mathrm{TH}(\mathrm{mg} / \mathrm{L})$ & $10.2-508.7$ & $9.4-164.6$ & $8.4-229.2$ & $25.9-257.7$ & $62.0-681.0$ & 500 & 150 \\
\hline $\mathrm{Ca}(\mathrm{mg} / \mathrm{L})$ & $2.6-107.0$ & $2.6-52.3$ & $2.2-73.4$ & $5.3-75.6$ & $0.3-54.9$ & 200 & - \\
\hline $\operatorname{Mg}(\mathrm{mg} / \mathrm{L})$ & $0.5-58.8$ & $0.7-8.6$ & $0.7-15.6$ & $2.3-16.8$ & $0.3-19.0$ & - & - \\
\hline $\mathrm{Na}(\mathrm{mg} / \mathrm{L})$ & $1.1-169.0$ & $2.1-64.5$ & $1.7-48.1$ & $1.9-72.4$ & $2.7-37.8$ & 200 & 200 \\
\hline $\mathrm{K}(\mathrm{mg} / \mathrm{L})$ & $0.3-143.0$ & $3.4-37.4$ & $1.8-76.9$ & $5.2-90.8$ & $0.9-53.3$ & 200 & - \\
\hline $\mathrm{Fe}(\mu \mathrm{g} / \mathrm{L})$ & $30.0-3050.0$ & $20.0-4330.0$ & $40.0-2640.0$ & $40.0-3100.0$ & $40.0-620.0$ & 300 & 300 \\
\hline $\operatorname{Mn}(\mu \mathrm{g} / \mathrm{L})$ & $10.0-610.0$ & $10.0-370.0$ & $10.0-260.0$ & $10.0-210.0$ & $10.0-100.0$ & 400 & 200 \\
\hline $\mathrm{Cu}(\mu \mathrm{g} / \mathrm{L})$ & $2.0-186.0$ & $2.0-54.0$ & $2.0-57.0$ & $2.0-30.0$ & $2.0-20.0$ & 1000 & 1000 \\
\hline $\mathrm{Pb}(\mu \mathrm{g} / \mathrm{L})$ & $10.0-100.0$ & $10.0-20.0$ & $10.0-20.0$ & $10.0-10-0$ & $10.0-10.0$ & 10 & 10 \\
\hline $\mathrm{Zn}(\mu \mathrm{g} / \mathrm{L})$ & $5.0-1720$ & $5.0-462.0$ & $5.0-210.0$ & $5.0-353.0$ & $6.0-508.0$ & 3000 & 3000 \\
\hline $\mathrm{Co}(\mu \mathrm{g} / \mathrm{L})$ & $2.0-49.0$ & $2.0-4.0$ & $2.0-7.0$ & $2.0-6.0$ & $2.0-5.0$ & - & - \\
\hline $\mathrm{HCO}_{3}(\mathrm{mg} / \mathrm{L})$ & $10.4-439.3$ & $17.7-194.7$ & $7.3-243.5$ & $12.2-94.2$ & $36.61-277.6$ & 240 & - \\
\hline $\mathrm{SO}_{4}(\mathrm{mg} / \mathrm{L})$ & $3.2-219.8$ & $14.6-94.6$ & $6.5-155.4$ & $8.2-167.4$ & $8.2-167.4$ & 250 & 200 \\
\hline $\mathrm{Cl}(\mathrm{mg} / \mathrm{L})$ & $1.8-124.6$ & $4.9-42.0$ & $2.8-52.5$ & $21.3-197.4$ & $6.3-87.5$ & 250 & 250 \\
\hline $\mathrm{NO}_{3}(\mathrm{mg} / \mathrm{L})$ & $0.01-4.4$ & $0.01-1.6$ & $0.02-5.2$ & $0.2-1.5$ & $0.2-1.0$ & 50 & 50 \\
\hline
\end{tabular}

The values of $\mathrm{Pb}$ in excess of approved WHO standard value in the study area occur in few locations close to mechanic workshops and market waste dumps. The leaching of waste materials in a few locations into the subsurface may probably be the source of lead in groundwater.

Further evaluation of analytical results based on rock types indicate that among major cations, $\mathrm{K}^{+}$was dominant in migmatite and quartzite/quartz-schist rocks constituting $34.11 \%$ and $35.0 \%$ of the total cation concentrations, respectively. $\mathrm{Ca}^{2+}$ was dominant in finemedium grained granites constituting $40.0 \%$ while $\mathrm{Na}^{+}$ was dominant in the porphyritic granites constituting $41.68 \%$ of the total cations concentrations. $\mathrm{Mg}^{2+}$ was of secondary importance in the groundwater of the study area as it represents less than $8.5 \%$ of the cations concentrations in the various rock types with the exception of migmatite where it constitute $10.21 \%$ (Fig. 3). Furthermore, cations concentrations show the lowest values in charnockitic rocks (Fig. 3). The order of cations abundance vary considerably based on rock types. However, the order of their abundance follow similar trend of $\mathrm{K}^{+}>\mathrm{Ca}^{2+}>\mathrm{Na}^{+}>\mathrm{Mg}^{2+}$ in migmatite and quartzite/quartz-schist, $\mathrm{Ca}^{2+}>\mathrm{K}^{+}>\mathrm{Na}^{+}>\mathrm{Mg}^{2+}$ in fine medium grained granite and charnockite while the trend of $\mathrm{Na}^{+}>\mathrm{Ca}^{2+}>\mathrm{K}^{+}>\mathrm{Mg}^{2+}$ in porphyritic granite was distinct from other rock types. The distinct order of cations abundance in porphyritic granite might be the result of its chemical composition of this rock type that is rich in sodic feldspar.

Among the major anions, $\mathrm{HCO}_{3}{ }^{-}$was dominant in all rocks except schist/quartz-schist where $\mathrm{Cl}^{-}$was dominant

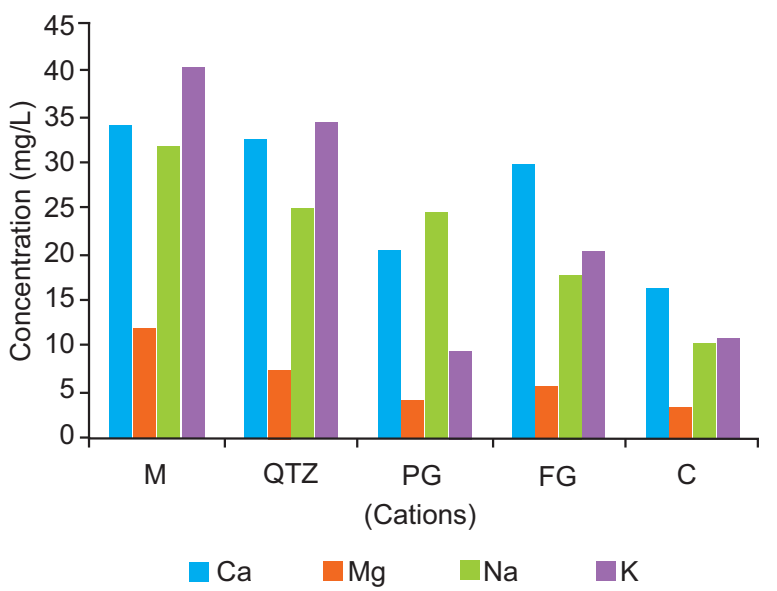

Fig. 3. Mean concentration of major cations based on rock types. $\mathrm{M}=$ migmatite; $\mathrm{QTZ}=$ quartzite/quartz-schist; $\mathrm{PG}=$ porphyritic granite; $\mathrm{FG}$ = fine-medium grained granite; $\mathrm{C}=$ charnockite 
(Fig. 4). Similar concentrations trend of $\mathrm{HCO}_{3}{ }^{-}>\mathrm{Cl}^{-}$ $>\mathrm{SO}_{4}{ }^{2-}>\mathrm{NO}_{3}{ }^{-}$was observed in migmatite and charnockitic rocks while the concentrations trend of $\mathrm{HCO}_{3}{ }^{-}$ $>\mathrm{SO}_{4}{ }^{2-}>\mathrm{Cl}^{-}>\mathrm{NO}_{3}{ }^{-}$was observed in porphyritic granite and fine-medium grained granite. Distinct concentrations trend of $\mathrm{Cl}^{-}>\mathrm{SO}_{4}{ }^{2-}>\mathrm{HCO}_{3}>\mathrm{NO}_{3}{ }^{-}$was observed in schist/ quartz-schist. This variability is expected considering the heterogeneity of the basement rocks that respond to weathering differently and the localized nature of the basement aquifers. The dominance of $\mathrm{HCO}_{3}{ }^{-}$ion may be attributed to $\mathrm{CO}_{2}$ charged meteoric water that produce weak carbonic acid that later dissociates into hydrogen ions and bicarbonate ions as expressed in the equation below:

$$
\begin{aligned}
& \mathrm{CO}_{2}(\mathrm{~g})+\mathrm{H}_{2} \mathrm{O}(\mathrm{l}) \rightarrow \mathrm{H}_{2} \mathrm{CO}_{3}(\mathrm{aq}) \\
& \mathrm{H}_{2} \mathrm{CO}_{3}(\mathrm{aq}) \rightarrow \mathrm{H}^{+}(\mathrm{aq})+\mathrm{HCO}_{3}(\mathrm{aq})
\end{aligned}
$$

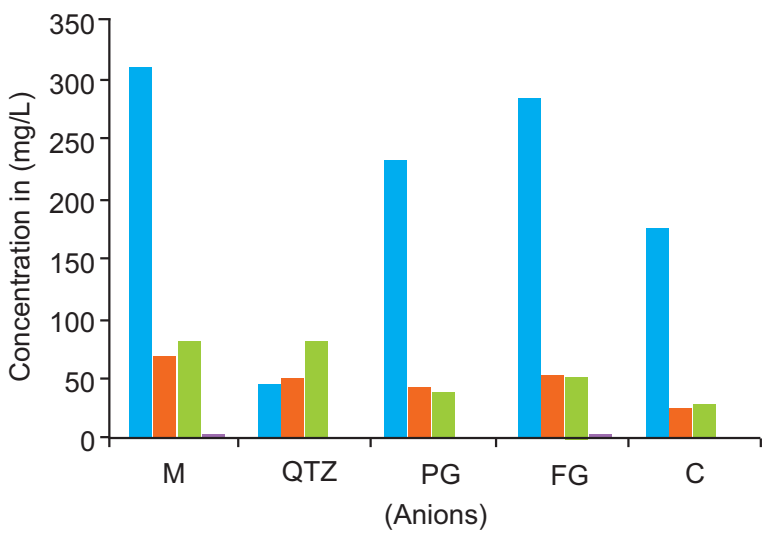

$\square \mathrm{HCO}_{3-} \mathrm{mg} / \mathrm{L} \square \mathrm{SO}_{4}^{2-} \mathrm{mg} / \mathrm{L} \quad \mathrm{Cl}-\mathrm{mg} / \mathrm{L} \square \mathrm{NO}_{3^{-}} \mathrm{mg} / \mathrm{L}$

Fig. 4. Mean concentration of major anions based on rock types. $\mathrm{M}=$ migmatite; $\mathrm{QTZ}=$ quartzite/quartz-schist; $\mathrm{PG}=$ porphyritic granite; $\mathrm{FG}=$ fine-medium grained granite; $\mathrm{C}=$ charnockite.
Furthermore, correlation analysis between various attributes of shallow groundwater in the study area has been done and is presented in Table 3. The EC is strongly correlated with $\mathrm{TH}, \mathrm{Ca}, \mathrm{Mg}$ and $\mathrm{Na}$. Among the anions, with the exception of $\mathrm{NO}_{3}, \mathrm{HCO}_{3}, \mathrm{SO}_{4}$ and $\mathrm{Cl}$ show high correlation with EC. The results show that the dissolved ions in the groundwater are responsible for EC. The hardness is strongly correlated with the major ions, with the exception of $\mathrm{NO}_{3}$, indicating that the hardness result from geogenic input of the dissolved ions rather than from anthropogenic activity. In addition, the relatively strong correlation of the major ions is an indication that the ions are guided by the same geochemical factors and were found within the same geochemical environment. However, the poor correlation of $\mathrm{NO}_{3}{ }^{-}$with other measured parameters indicates that it comes from a different source i.e. anthropogenic source rather than geogenic. Similarly, the major exchangeable ions $\mathrm{Na}$ and $\mathrm{Ca}, \mathrm{Na}$ and $\mathrm{Mg}$ correlate positively. The fact that groundwater electrical conductivity is a reflection of the total ions is supported by the observed relatively high positive correlation (0.98) between these parameters (Fig. 5). In view of the above highlighted observations, the concurrent variations in the composition of ions in the groundwater of the study area is probably predominantly due to the result of dissolution/precipitation reaction and ions concentration effects.

Mechanism controlling groundwater chemistry of the study area. Knowledge of processes that control groundwater composition is required for a rational management of water quality. The concentration of dissolved ions in groundwater samples are generally governed by lithology, nature of geochemical reactions and solubility of the aquifers rocks (Nosrat and Asghar,

\begin{tabular}{|c|c|c|c|c|c|c|c|c|c|c|c|}
\hline Parameters & $\mathrm{Ca}$ & $\mathrm{Mg}$ & $\mathrm{Na}$ & $\mathrm{K}$ & $\mathrm{HCO}_{3}$ & $\mathrm{SO}_{4}$ & $\mathrm{Cl}$ & $\mathrm{NO}_{3}$ & $\mathrm{TH}$ & $\mathrm{pH}$ & $\mathrm{EC}$ \\
\hline $\mathrm{Ca}$ & 1.000 & - & - & - & - & - & - & - & - & - & - \\
\hline $\mathrm{Mg}$ & 0.733 & 1.000 & - & - & - & - & - & - & - & - & - \\
\hline $\mathrm{Na}$ & 0.525 & 0.556 & 1.000 & - & - & - & - & - & - & - & - \\
\hline K & 0.674 & 0.472 & 0.543 & 1.000 & - & - & - & - & - & - & - \\
\hline $\mathrm{HCO}_{3}$ & 0.879 & 0.810 & 0.781 & 0.754 & 1.000 & - & - & - & - & - & - \\
\hline $\mathrm{SO}_{4}$ & 0.599 & 0.658 & 0.553 & 0.613 & 0.682 & 1.000 & - & - & - & - & - \\
\hline $\mathrm{Cl}$ & 0.753 & 0.662 & 0.819 & 0.698 & 0.837 & 0.570 & 1.000 & - & - & - & - \\
\hline $\mathrm{NO}_{3}$ & 0.242 & 0.078 & 0.002 & 0.320 & 0.186 & 0.260 & 0.120 & 1.000 & - & - & - \\
\hline $\mathrm{TH}$ & 0.959 & 0.895 & 0.574 & 0.638 & 0.912 & 0.665 & 0.768 & 0.191 & 1.000 & - & - \\
\hline $\mathrm{pH}$ & 0.649 & 0.330 & 0.343 & 0.562 & 0.557 & 0.363 & 0.577 & 0.064 & 0.562 & 1.000 & - \\
\hline $\mathrm{EC}$ & 0.897 & 0.800 & 0.754 & 0.762 & 0.953 & 0.670 & 0.830 & 0.215 & 0.920 & 0.522 & 1.000 \\
\hline
\end{tabular}

Table 3. Correlation analysis of physico-chemical parameters of the groundwater samples 


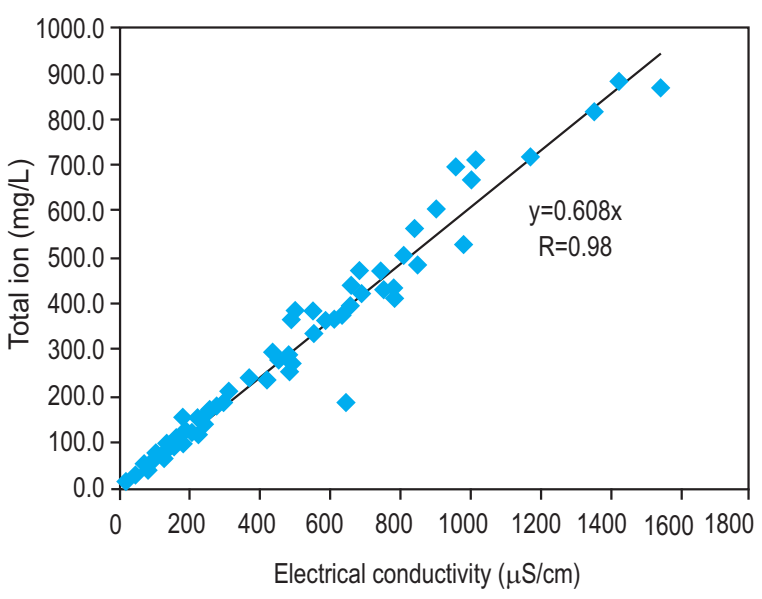

Fig. 5. A correlation plot between total ions and specific electrical conductivity.

2010). Gibbs (1970) had pointed out that the rate of evaporation, chemical composition of rocks and chemical composition of rainwater generally control the chemistry of water.

In order to evaluate the sources of various ions in the groundwater of the study area, a plot of the TDS against $\mathrm{Na}^{+} /\left(\mathrm{Na}^{+}+\mathrm{Ca}^{2+}\right)$ ratio (Fig. 8), indicate that the groundwaters may have modified their chemistry from the weathered materials derived from the underlying bedrocks. The diagram of (Gibbs, 1970) indicate that $47.72 \%$ of the groundwater samples representing 42 out of total 88 samples are in the rock dominant category while the rest fall in the dilution field. The dilution effect is pronounced due to the period of sampling i.e. peak of the rainy season (July, 2008). Rock dominance of almost half of the samples is caused by the interaction between the aquifer rocks and groundwater.

Drinking water quality assessment. The main objective of hydrogeochemical assessment is to determine groundwater suitability for different uses based on different chemical indices. In this study, assessment of the suitability for drinking and domestic uses was evaluated by comparing the hydrochemical parameters of groundwater in the study area with the prescribed specification of World Health Organization (WHO, 2004) and Standard Organisation of Nigeria (SON, 2007) (Table 2).

The $\mathrm{pH}$ values of the groundwater vary between 6.07.8 , indicating slight acidity to moderate alkaline nature of the groundwater. According to the WHO, the range of desirable $\mathrm{pH}$ values of water prescribed for drinking purposes is 6-9 (WHO, 2004) while that of SON (2007) is between 6.5-8.5. Water samples in few locations fall outside the desirable $\mathrm{pH}$ values. This slight increase in $\mathrm{H}^{+}$ions probably resulted from the generation of carbonic acid from intensive rainfall that characterized the sampling period. Table 2 shows that few of the parameters exceed the maximum permissible limits of WHO (2004). The EC and concentration of TDS is more than the maximum permissible limits of $1500 \mu \mathrm{S} / \mathrm{cm}$ and $1000 \mathrm{mg} / \mathrm{L}$, in $1.0 \%$ and $3.0 \%$ of the total groundwater samples, respectively. The recommended limit for sodium concentration in drinking water is $200 \mathrm{mg} / \mathrm{L}$. A higher sodium intake may cause hypertension, congenial heart diseases and kidney problems (Singh et al., 2008). Sodium concentrations was within the prescribed limit of $200 \mathrm{mg} / \mathrm{L}$ in all analyzed groundwater samples of the study area. The overall drinking water quality assessment revealed that the chemical profiles, with very few exceptions, are within the permissible limits of WHO (2004) and SON (2007) standards and as such suitable for drinking purpose.

Suitability for irrigation purpose. Knowledge of irrigation water quality can influence crop productivity more than soil fertility, hybrid, weed control and other strategies and is critical to understanding agricultural management for long-term productivity. The water quality evaluation in this study was carried out to determine its suitability for agricultural purposes. The suitability of groundwater for agricultural purpose is based on the effects of the total salt content, sodium and specific ion toxicities of the water on both the plant and the soil. In fact, salts can be highly harmful, and can limit plants growth physically by restricting the water uptake through modification of osmotic processes. Also salts may damage plant growth chemically by the effects of toxic substances upon metabolic processes. For this study salinity, alkali and magnesium hazards are considered for evaluation of the suitable quality of groundwater for irrigation as highlighted below.

Salinity hazard. The most influential water quality guideline on crop productivity is the water salinity hazard as measured by electrical conductivity (EC). The primary effect of high $\mathrm{EC}$ water on crop productivity is the inability of the plant to compete with ions in the soil solution for water (physiological drought). The higher the EC, the less water is available to plants, even though the soil may appear wet, this is due to the fact that usable plant water in the soil solution decreases dramatically as EC increases. The total soluble salt 
content of irrigation water generally is measured either by determining its electrical conductivity (EC), reported as micro Siemens per centimeter, or by determining the actual salt content in parts per million (ppm). In this study, the EC was determined based on the US Salinity Laboratory (1954) classification, the salinity hazard for groundwater samples in the study area is classified into three classes; low (C1), medium (C2) and high (C3) as presented in Fig. 6. Results show that 47 groundwater samples with EC $<500 \mu \mathrm{S} / \mathrm{cm}$, representing $53.42 \%$ of the total groundwater samples of the study area fall in the low salinity hazard category $(\mathrm{C} 1), 26$ groundwater samples representing $29.54 \%$ with $500<\mathrm{EC}<1000 \mu \mathrm{S} / \mathrm{cm}$ are in the medium category (C2) while 15 of the total groundwater samples representing $17.04 \%$ with $\mathrm{EC}>1000 \mu \mathrm{S} / \mathrm{cm}$ belong to the high salinity hazard category (C3). Normally, irrigation water with an EC of $<700 \mu \mathrm{S} / \mathrm{cm}$ causes little or no threat to most crops while EC $>3000 \mu \mathrm{S} / \mathrm{cm}$ may limit their growth (Tijani, 1994). Thus groundwater in the low salinity hazard category can be used as irrigation water on all soils while those in the medium salinity hazard can be used in most cases as irrigation water without any special practices for salinity control. However, water samples that fall in the high salinity hazard class (C3) may have detrimental effects on salt sensitive crops and, in certain cases, it may adversely affect many plants. Irrigation

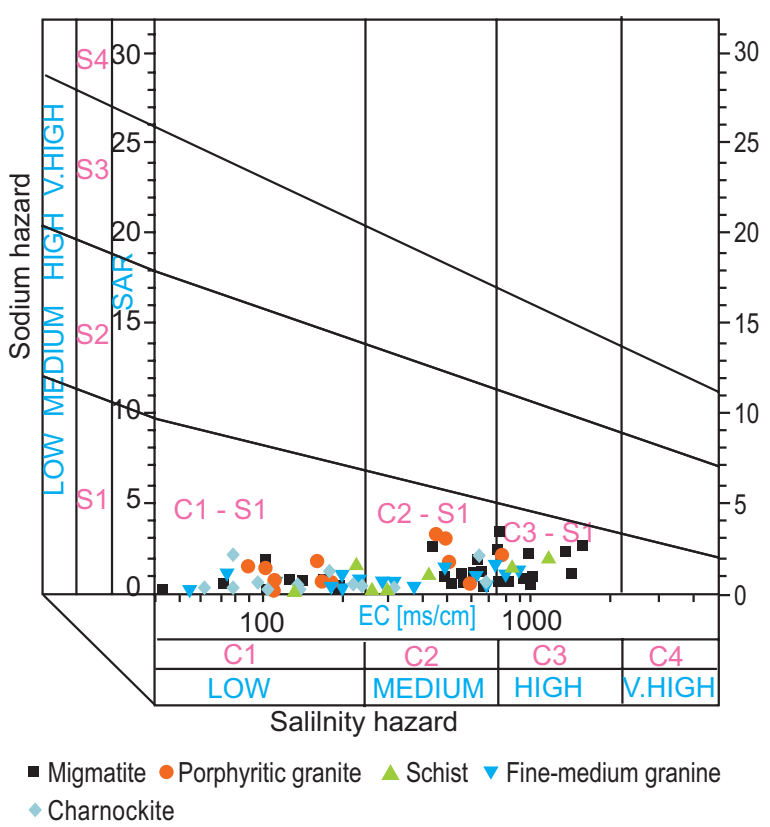

Fig. 6. Salinity diagram for classification of irrigation waters (Based on Richards, 1954). in such areas require careful management practices. Low to high salinity hazards cut across migmatite, quartzite/quartz-schist and fine-medium grained granite settings while groundwater samples from porphyritic granite and charnockite are restricted to low to medium salinity hazards. The high salinity hazard in some of the groundwater samples could probably have resulted from soluble mineral materials along the flow path of groundwater and also from dissolution of the chemical fertilizers by irrigation water and municipal waste disposal.

Alkali hazard. Although plant growth is primarily effected by the salinity (EC) level of the irrigation water, the application of water with a sodium imbalance can further reduce yield under certain soil texture conditions. Reductions in water infiltration can occur when irrigation water contains higher sodium than calcium and magnesium contents. A high salt content (high EC) in water leads to formation of saline soil while high sodium content (SAR) leads to development of an alkaline soil (Khodapanah et al., 2009). The alkali hazard is typically expressed as the sodium adsorption ratio (SAR). This index quantifies the proportion of sodium $(\mathrm{Na})$ to calcium $(\mathrm{Ca})$ and magnesium $(\mathrm{Mg})$ ions in a sample. The SAR assesses the potential for infiltration problems due to a sodium imbalance in irrigation water. The SAR is mathematically computed using the following formula given by Richards (1954).

$$
\mathrm{SAR}=\frac{\mathrm{Na}^{+}}{\sqrt{\frac{\left(\mathrm{Ca}^{2+}\right)+\left(\mathrm{Mg}^{2+}\right)}{2}}}
$$

Ions in the equation are expressed in milliequivalent per litre. The SAR values plotted on the US salinity diagram as alkalinity hazard shows that all groundwater samples in the study area have $\mathrm{SAR}<10$ i.e. SAR range between 0.15-4.98 and consequently fall in the low sodium hazard category. As per alkali hazard classification by Richard (1954), water with $\mathrm{EC}<250 \mu \mathrm{S} / \mathrm{cm}$ and $\mathrm{SAR}<10$ are in the excellent irrigation water category while those with $250<\mathrm{EC}<750 \mu \mathrm{S} / \mathrm{cm}$ and $10=\mathrm{SAR}<18$ are in good irrigation water quality. Based on this classification, 26 out of 37 groundwater samples from migmatite rock unit are in the excellent to good irrigation water category. In addition, 13 out of 14 samples, 6 out of 7 samples, 14 out of 17 samples and the whole 13 samples in porphyritic granite, quartz-schist, finemedium grained granite and charnockite, respectively fall in this same class of irrigation water. In all, 72 out 
of 88 groundwater samples are in excellent to good category implying the suitability of greater proportion of the groundwater system in the study area for irrigation purpose. As for the doubtful water category, with 750 $\mathrm{EC} \leq 2250 \mu \mathrm{S} / \mathrm{cm}$, groundwater samples from migmatite bedrock settings has the greatest value of 12 out of 37 groundwater samples. The high EC values on migmatite is not unexpected; migmatite being a composite silicate metamorphic rock, pervasively heterogeneous on a meso to macroscopic scale with variable mineral dissolutions in groundwater and in few locations, domestic waste dumps contribute to the high EC values.

Magnesium hazard. Calcium and magnesium exist as positively charged ions in water and they counteract the deleterious effect of sodium through cation exchange process. For plant growth $\mathrm{Ca}$ and $\mathrm{Mg}$ are essential but at times, they may associate with soil aggregation and friability by destroying soil structure. A state of equilibrium is maintained by $\mathrm{Ca}^{2+}$ and $\mathrm{Mg}^{2+}$ in groundwater (Hem, 1985). However, during equilibrium, an increase in $\mathrm{Mg}^{2+}$ will adversely affect the soil quality rendering it alkaline which could result in decrease of crop yield (Kumar et al., 2007). Paliwal (1972) developed an index for calculating the magnesium hazard $(\mathrm{MH})$. The $\mathrm{MH}$ is calculated using the formula:

$$
\mathrm{MH}=\mathrm{Mg}^{2+} /\left(\mathrm{Ca}^{2+}+\mathrm{Mg}^{2+}\right) \times 100
$$

In the study area, evaluated chemical data revealed that the $\mathrm{MH}$ values range from 3.80 to 76.42 with average value of 31.11 . Furthermore, 93\% of groundwater samples i.e. 82 out of 88 samples fall within permissible limit of 50 while only 6 samples (3 in migmatite, 1 in fine-medium grained granite, 1 in quartz-schist, 1 in charnockite) fall outside the limit (Paliwal, 1972).

Water classification for irrigation utility. In order to classify the groundwater samples from the study area for irrigation uses $\mathrm{Na} \%=\left(\mathrm{Na}^{+}\right) * 100 /\left(\mathrm{Ca}^{2+}+\mathrm{Mg}^{2+}+\right.$ $\mathrm{Na}^{+}+\mathrm{K}^{+}$) was estimated for each sample where, the quantities of all cations are expressed in milliequivalents per litre (epm). Sodium percentage $(\mathrm{Na} \%)$ in the study area generally ranges between 5.97-53.14\% with exception of few higher values (78.96 in charnockite, 66.95 in migmatite, 63.58 and 61.36 in porphyritic granite bedrock settings). These high values derive from waste dumps' leachates in few highlighted locations that add to geogenic solutes from weathering and dissolution of rocks and minerals. Based on Sadashivaiah et al. (2008) the classification of groundwater for irrigation purposes was grouped as excellent $(<20 \%)$, good (20-40\%), permissible (40-60\%), doubtful (60$80 \%)$ and Unsuitable ( $>80 \%$ ) based on sodium percentage. From the estimated $\mathrm{Na} \%$ of the study area, 66 out of the 88 groundwater samples with $28,7,5,16$ and 10 samples from migmatite, porphyritic granite, quartzschist, fine-medium grained granite and charnockite bedrock settings, respectively have excellent to good irrigation water quality. Also, 15 out of the 88 samples with 7, 4, 1, 1 and 2 samples from migmatite, porphyritic granite, quartz-schist, fine-medium grained granite and charnockite rock units, respectively have permissible irrigation water quality. None of the samples have unsuitable irrigation water quality but 8 of them with 3 samples from migmatite, 3 samples from porphyritic granite and 1 sample each from quartz-schist and charnockite bedrock settings, respectively have doubtful irrigation water quality. Furthermore, the US Salinity Laboratory Diagram (USDA, 1954) in which salinity hazard was plotted against sodium hazard (Fig. 6), indicates that all the groundwater samples from the study area fall in low sodium hazard with estimated SAR range values of 0.15-4.98 while their salinity hazard range from low to high i.e. low salinity has $\mathrm{EC}<$ $500 \mu \mathrm{S} / \mathrm{cm}$, medium salinity has $500<\mathrm{EC}<1000 \mu \mathrm{S} / \mathrm{cm}$ while high salinity has EC $>1000 \mu \mathrm{S} / \mathrm{cm}$. Nine (9) out of the 13 samples in high salinity hazard are in the migmatite bedrock. The high salinity in migmatite bedrock may be from geogenic dissolution of minerals and probably from anthropogenic source due to refuse dumps close to sampling points.

In addition, Wilcox (1955) irrigation classification diagram (Fig. 7), classified the groundwater in the study area into two classes; (1) excellent to good irrigation water with $\mathrm{EC}<750 \mu \mathrm{S} / \mathrm{cm}$ and (2) doubtful to permissible irrigation water category with $750<\mathrm{EC}<2000 \mu \mathrm{S} / \mathrm{cm}$. Groundwater samples from migmatite still dominate the doubtful to permissible irrigation class which support the earlier observation from US Salinity Laboratory diagram (USDA, 1954). The highlighted irrigation quality profiles revealed that, the groundwater in the study area is suitable for irrigation in most cases, except in a few locations with high salinities.

Characterization of the groundwater system of the study area. Groundwater characterisation constitute one of the vital tools for sustainable development and provides important information for water management. It entails fishing out groundwater bodies that are at risk of failing to meet the approved water standards for domestic, industrial and agricultural utilization. 


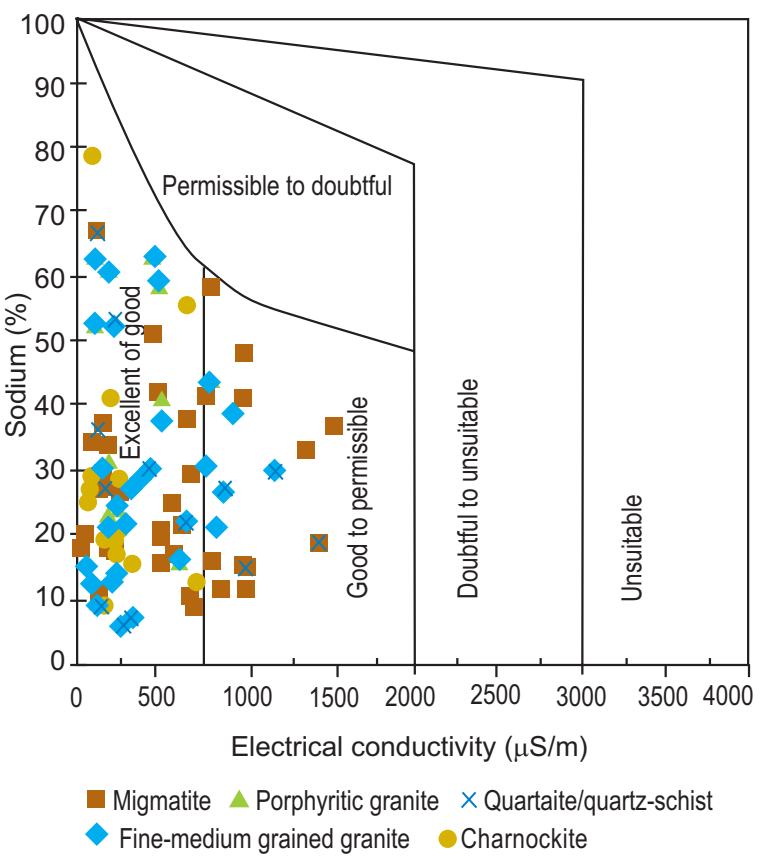

Fig. 7. Plot of sodium percentage and electrical conductivity (Based on Wilcox, 1955) for classification of Groundwater for irrigation uses.

In the study area, 85 out of 88 groundwater samples representing $96.59 \%$ (Table 4 ) have TDS $<1000 \mathrm{mg} / \mathrm{L}$ and is classified as freshwater based on water classification after Freeze and Cherry (1979). The remaining three (3) samples representing 3.41\% exceeded TDS value of $1000 \mathrm{mg} / \mathrm{L}$ possibly as a consequence of contamination from waste dumps close to these few wells located on migmatite bedrock.

Furthermore, the total hardness (TH) of the groundwater samples in the study area was calculated using the formula of Sawyer et al. (2003), as given below:

$\mathrm{TH}\left(\right.$ as $\left.\mathrm{CaCO}_{3}\right) \mathrm{mg} / \mathrm{L}=\left(\mathrm{Ca}^{2+}+\mathrm{Mg}^{2+}\right) \mathrm{meq} / \mathrm{L} * 50$.
Table 4. Classification of groundwaters (Freeze and Cherry, 1979)

\begin{tabular}{llll}
\hline \hline Water (Types) & $\begin{array}{l}\text { No. of } \\
\text { samples }\end{array}$ & $\begin{array}{l}(\%) \\
\text { Samples }\end{array}$ & $\begin{array}{l}\text { Total dissolved } \\
\text { solids }(\mathrm{mg} / \mathrm{L})\end{array}$ \\
\hline Fresh water type & 85 & 96.59 & $<1000$ \\
Brackish water type & 3 & 3.41 & $1000-10000$ \\
Saline water type & - & - & $10000-100000$ \\
Brine water type & - & - & $>100,000$ \\
Total & 88 & 100 & \\
\hline \hline
\end{tabular}

The hardness values range from 10.2 to $289.1 \mathrm{mg} / \mathrm{L}$ with an average value of $102.40 \mathrm{mg} / \mathrm{L}$ except in locations C12, FG15, PG3 and M22 with hardness values of 3.2, $8.4,9.4$ and $508.7 \mathrm{mg} / \mathrm{L}$, respectively. Water hardness is primarily the amount of calcium and magnesium and to a lesser extent, iron in the water is commonly expressed as milligrams of calcium carbonate equivalent per litre. Water containing calcium carbonate at concentrations below $60 \mathrm{mg} / \mathrm{L}$ is generally considered as soft; 60-120 mg/L, moderately hard; 120-180 mg/L, hard; and more than $180 \mathrm{mg} / \mathrm{L}$, very hard (McGowan, 2000). The classification of groundwater of the study area (Table 5) based on total hardness (TH) shows that 33 of the groundwater samples fall in the soft water category with the highest proportion from charnockitic bedrock setting i.e. 9 out of the 13 groundwater samples in that bedrock setting. This trend might be as a result of chemical composition of charnockitic rocks as many of the minerals of these rocks are schillerized, as they contain minute platy or rod-shaped inclusions and as such the mineral components when weathered are probably retained in the clay and may not easily dissolved into groundwater aquifers. Also, 24, 15 and 16 of the groundwater samples are in the moderately hard, hard and very hard categories, respectively. Groundwater in the very hard category are more represented in migmatite bedrock i.e. 11 out of 37 samples compared to 3 out of

Table 5. Groundwater classification based on hardness (McGowan, 2000)

\begin{tabular}{|c|c|c|c|c|c|c|c|c|}
\hline \multirow{2}{*}{$\begin{array}{l}\mathrm{TH} \text { as } \mathrm{CaCO}_{3} \\
(\mathrm{mg} / \mathrm{L})\end{array}$} & \multirow{2}{*}{$\begin{array}{l}\text { Water } \\
\text { (Types) }\end{array}$} & \multicolumn{5}{|c|}{ No. of samples on bedrock settings } & \multirow[t]{2}{*}{ Total } & \multirow{2}{*}{$\begin{array}{l}\text { Samples } \\
(\%)\end{array}$} \\
\hline & & M & PG & FG & QS & $\mathrm{C}$ & & \\
\hline$<60$ & Soft & 9 & 7 & 6 & 2 & 9 & 33 & 37.50 \\
\hline $60-120$ & Moderately hard & 9 & 5 & 5 & 2 & 3 & 24 & 27.27 \\
\hline $120-180$ & Hard & 8 & 2 & 3 & 2 & - & 15 & 17.05 \\
\hline$>180$ & Very hard & 11 & - & 3 & 1 & 1 & 16 & 18.18 \\
\hline Total & & 37 & 14 & 17 & 7 & 13 & 88 & 100.00 \\
\hline
\end{tabular}

$\overline{\mathrm{M}}=$ migmatite; $\mathrm{PG}$ = porphyritic granite; $\mathrm{FG}$ = fine to medium grained granite; $\mathrm{QS}$ = quartz-schist; $\mathrm{C}$ : Charnockite 
17 samples in fine to medium grained granite, 1 out of 7 samples in quartz-schist, 1 out of 13 samples in charnockite and none at all in porphyritic granite. This observation is consistent with the observed high values of TDS in few locations on migmatite bedrock close to refuse dumps.

Hydrochemical facies are water masses that have different geochemical attributes and are helpful for comparing the origins and distribution of groundwater system (Lloyd and Heathcote et al., 1985). Over the years, the Trilinear Piper diagrams are useful in bringing out chemical relationships among groundwater samples in more definite terms compared to other convectional plotting methods. The concept of hydrochemical facies was developed in order to understand and identify the water composition in different classes. Hydrochemical facies are distinct zones that possess cation and anion concentration categories (Rajendra et al., 2009). In case of a clear domination of a particular cation or anion ( $>50 \%$ of total cations or anions), the facies can be identified based on dominant constituents. In case of no clear-cut domination, $1 / 3$ or $33 \%$ is taken as cut-off value (Saha et al., 2008). Piper (1944) independently developed a diagram called Piper Trilinear diagram to explain the concept of hydrochemical facies. This concept was developed in order to understand and identify the water composition in different classes. The plots include two triangles, one for plotting cations and the other for plotting anions. The cations and anions

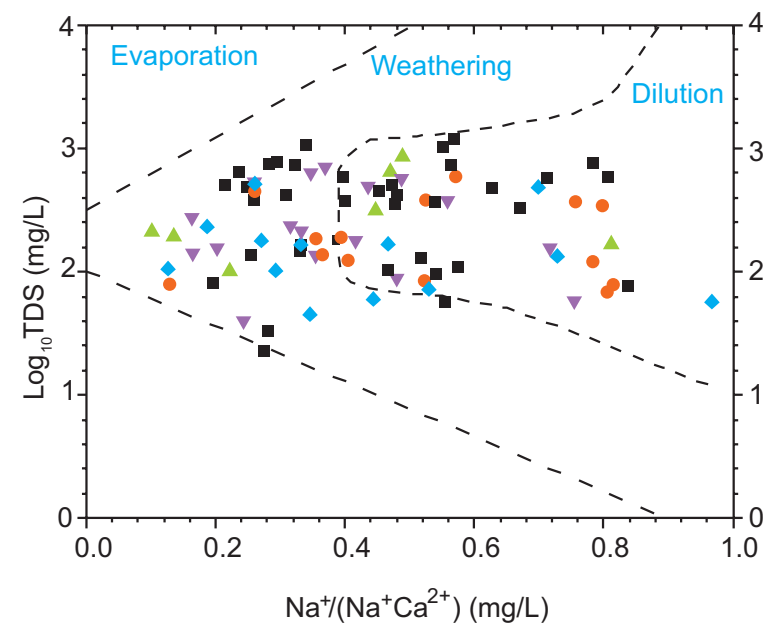

- Migmatite $\bullet$ Porphyritic granite $\Delta$ Schist $\nabla$ Fine-medium grain granite - Charnockite

Fig. 8. Plot of $\log (\mathrm{TDS})$ against the $\mathrm{Na} / \mathrm{Na}+\mathrm{Ca}$ (after Gibbs, 1970). fields are combined to show a single point in a diamondshaped field, from which inference is drawn on the basis of hydro-geochemical facies concept. In addition, Piper (1953) further developed an essentially similar diagram modifying the position of the triangles and the diamond shaped field (quadrilateral field) portion. Piper also gave a detailed description of the procedures and examples of application of this diagram to the geochemical interpretation of water analyses. The central diamond-shaped field (quadrilateral field) is used to show the overall chemical character of the water. Back et al. (1965) defined the subdivisions of the diamond field that represent water-type categories that form the basis for one common classification scheme for natural waters. The modified Piper diagram, with some changes as to the classification of the different water types was adopted for the interpretation of water facies in this study. To identify the various water facies in the study area, the groundwater samples were plotted in the Ppier Trilinear diagram (Fig. 9). Based on the relative dominance of major cations and anions, different hydrochemical facies with their relative percentages identified in the study area are presented in Table 6 .

The hydrochemical water facies of the study area include $\mathrm{CaHCO}_{3}$ (31 samples), $\mathrm{NaCl}$ (10 samples), mixed/ exchange water type $\mathrm{CaNaHCO}_{3}$ (19 samples), mixed/ exchange water type $\mathrm{CaMgCl}$ (25 samples) and $\mathrm{CaCl}$ (3 samples). The Piper diagram shows that most of the groundwater samples analyzed fall in the field of

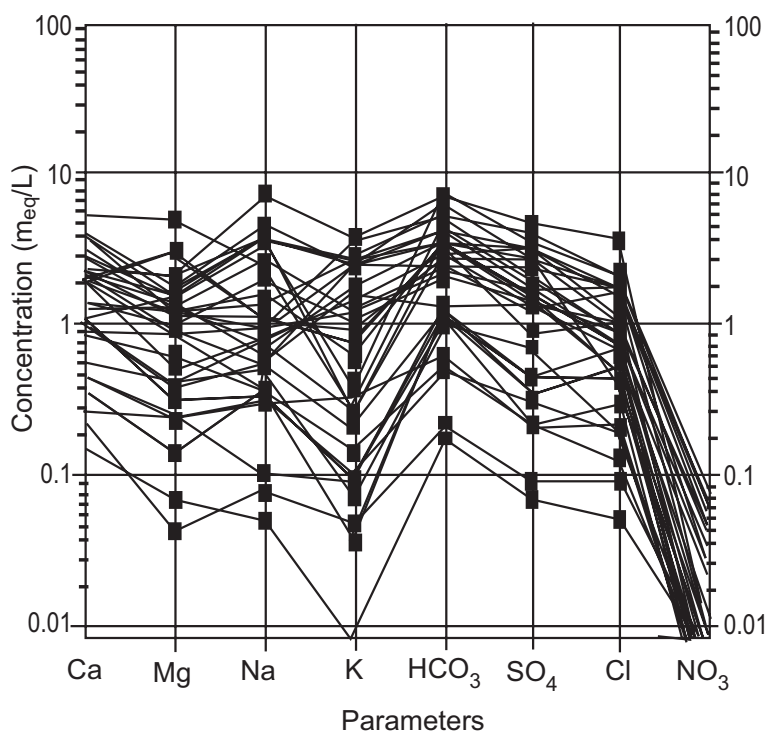

Fig. 9. Schoeller diagram for the groundwater samples. 
Table 6. Hydrochemical facies of groundwater in the study area

\begin{tabular}{lll}
\hline \hline Facies & No. of samples & Samples (\%) \\
\hline $\mathrm{CaHCO}_{3}$ & 31 & 35.23 \\
$\mathrm{NaCl}$ & 10 & 11.36 \\
$\mathrm{Mixed} \mathrm{CaNa} \mathrm{HCO}_{3}$ & 18 & 20.45 \\
Mixed $\mathrm{CaMgCl}$ & 25 & 28.41 \\
$\mathrm{CaCl}$ & 3 & 3.41 \\
$\mathrm{NaHCO}_{3}$ & 1 & 1.14 \\
Total & 88 & 100.00 \\
\hline \hline
\end{tabular}

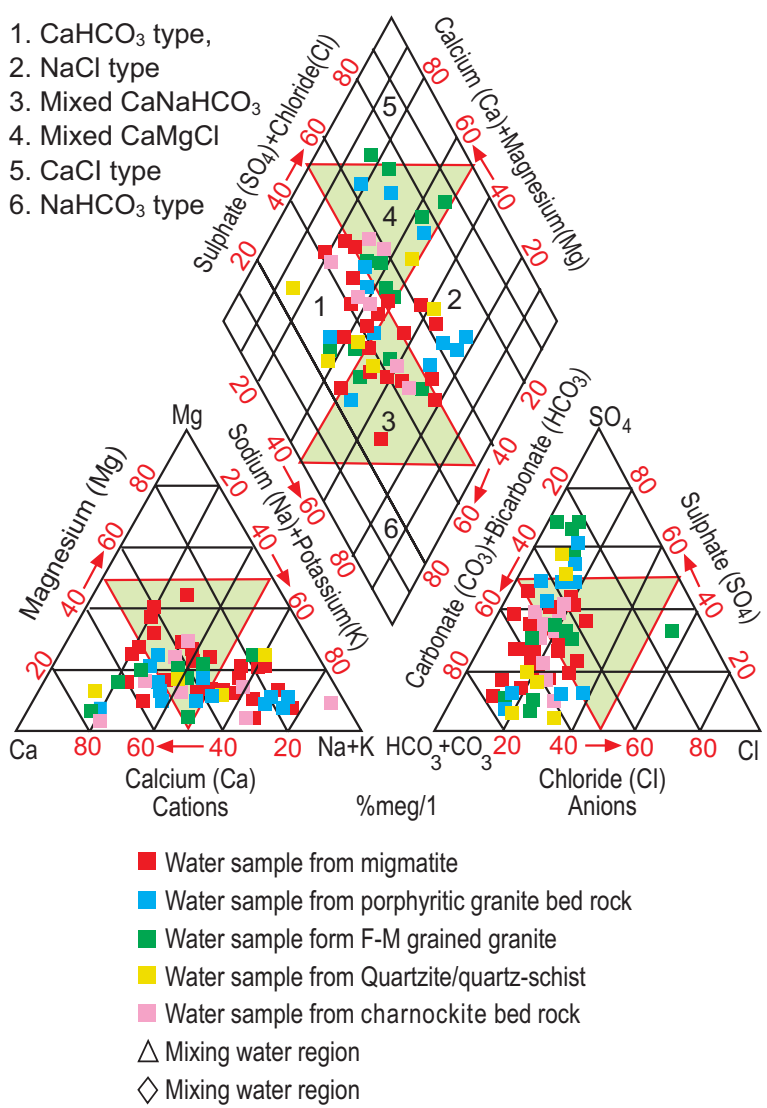

Fig. 10. Groundwater characterization; Piper diagram.

mixed/exchange water type that is, $\mathrm{CaMgCl}$ and $\mathrm{CaNaHCO}_{3}$ (43 samples) representing $48.86 \%$ of the analysed samples in the study area. Furthermore, alkali metals ( $\mathrm{Na}$ and $\mathrm{K}$ ) exceed alkaline earth metals ( $\mathrm{Ca}$ and $\mathrm{Mg}$ ) and strong acids exceed weak acids, which implies that the water chemistry of the study area is dominated by alkali and strong acids. In addition, the observed hydrochemical facies, signify that the dissolved ions are mainly geogenic with dominance of water-rock interactions.

\section{Conclusion}

The shallow groundwaters in the crystalline basement area of Ekiti, Southwestern Nigeria have been evaluated for their chemical composition and suitability for drinking and irrigation uses. The investigation indicates that the order of major cations abundance is $\mathrm{Ca}^{2+}>\mathrm{K}^{+}$ $>\mathrm{Na}^{+}>\mathrm{Mg}^{2+}$ while that of the anions is $\mathrm{HCO}_{3}{ }^{-}>\mathrm{SO}_{4}{ }^{2-}$ $>\mathrm{Cl}^{-}>\mathrm{NO}_{3}{ }^{-}$. However, the order of ions abundance is variable based on rock types with similar order of cations abundance of $\mathrm{K}^{+}>\mathrm{Ca}^{2+}>\mathrm{Na}^{+}>\mathrm{Mg}^{2+}$ in migmatite and quartzite/quartz-schist, $\mathrm{Ca}^{2+}>\mathrm{K}^{+}>\mathrm{Na}^{+}>\mathrm{Mg}^{2+}$ in fine-medium grained granite and charnockite while the trend is $\mathrm{Na}^{+}>\mathrm{Ca}^{2+}>\mathrm{K}^{+}>\mathrm{Mg}^{2+}$ in porphyritic granite distinct from other rock types in view of its chemical composition that is rich in sodic feldspar. As regards the major ions, $\mathrm{HCO}_{3}{ }^{-}$was dominant in all the rocks except schist/quartz-schist where $\mathrm{Cl}^{-}$was dominant. Similar concentrations trend of $\mathrm{HCO}_{3}{ }^{-}>\mathrm{Cl}^{-}>\mathrm{SO}_{4}{ }^{2-}$ $>\mathrm{NO}_{3}{ }^{-}$was observed in migmatite and charnockitic rocks while the concentrations trend of $\mathrm{HCO}_{3}{ }^{-}>\mathrm{SO}_{4}{ }^{2-}$ $>\mathrm{Cl}^{-}>\mathrm{NO}_{3}{ }^{-}$was observed in porphyritic granite and fine-medium grained granite. Distinct concentrations trend of $\mathrm{Cl}^{-}>\mathrm{SO}_{4}{ }^{2-}>\mathrm{HCO}_{3}{ }^{-}>\mathrm{NO}_{3}{ }^{-}$was observed in schist/quartz-schist. Furthermore, with over $90 \%$ of the groundwater having TDS $<1000$, TH $<500$ and low chemical concentration trends in different rock types imply low mineralized soft groundwater system with limited residence time and limited water-rock interaction.

The overall drinking quality assessment indicates that most of the hydrochemical parameters satisfy WHO (2004) and SON (2007) standard values for drinking water except in few locations where $\mathrm{Pb}, \mathrm{Fe}$ and $\mathrm{Mn}$ exceeded the standard values. Wilcox and US Laboratory Salinity Staff diagrams revealed that most of the groundwater samples are suitable for irrigation purposes under normal condition. The salinity hazard for shallow groundwater system in the study area is classified as low $(\mathrm{EC}<500 \mu \mathrm{S} / \mathrm{cm})$, medium $(500<\mathrm{EC}<1000 \mu \mathrm{S} / \mathrm{cm})$ and high salinity $(\mathrm{EC}>1000 \mu \mathrm{S} / \mathrm{cm})$ classes with 47 , 26 and 15 samples in the respective classes. Alkali hazard, with values ranging from 0.15 to 4.98 , is classified as low in the study area with only 12 out of 88 groundwater samples showing high salinity hazard. Moreover, the estimated SAR values of less than 10 for all groundwater samples in the study area is indicative of good irrigation water, suitable on all agricultural soils. The chemistry of groundwater evolution depends on chemical inputs from precipitation $\left(\mathrm{CO}_{2}\right.$ - charged rainwater), chemical 
weathering and dissolution of the parent bedrocks. Hence, the resulting groundwater is largely characterised as $\mathrm{CaHCO}_{3}$ water type with relatively low TDS. In addition, mixed/exchange water types $\left(\mathrm{CaNaHCO}_{3}\right.$ and $\mathrm{CaMgCl}$ ) as well as scoops of $\mathrm{NaCl}$ water type exist in the groundwater system of the study area. Finally, this study has revealed the hydrochemical profiles of groundwater in the study area. However, the relatively high values of lead, iron and manganese contents in the groundwater of the study area demand for further investigation.

\section{References}

Ademilua, L.O., Olorunfemi, M.O. 2000. A geoelectric/ geology estimation of the groundwater potential of the basement complex area of Ekiti and Ondo States, Nigeria. Journal of Technoscience, 4: 4-18.

Ako, B.D., Olorunfemi, M.O. 1989. Geoelectric survey for groundwater in the Newer Basalts of Vom, Plateau State. Nigerian Journal of Mining and Geology, 25: 247-450.

Babiker, I.S., Mohamed, A.A., Hiyama, T. 2007. Assessing groundwater quality using GIS. Water Resources Management, 21: 699-715.

Berner, E.K., Berner, R.A. 1987. The Global Water Cycle: Geochemistry and Environment, 397 pp., Prentice Hall, Eaglewood Cliffs, New Jersey, USA.

Bolarinwa, A.T., Elueze, A.A. 2005. Geochemical trends in weathered profiles above granite gneiss and schists of Abeokuta area, Southwestern Nigeria. Journal of Mining and Geology, 41: 19-31.

Ehinola, O.A. 2002. Hydrochemical characteristics of ground water in parts of the basement complex of Southwestern Nigeria. Journal of Mining and Geology, 38: 125-133.

Elueze, A.A., Omidiran, J.O., Nton, M.E. 2004. Hydrochemical investigation of surface water and groundwater around Ibokun, Ilesha area, Southwestern Nigeria. Journal of Mining and Geology, 40: 57-64.

Freeze, R.A., Cherry, J.A. 1979. Groundwater, 604 pp., Prentice-Hall, Inc. Englewood Cliffs, New Jersey, USA.

Gibbs, R.J. 1970. Mechanisms controlling world water chemistry. Science, 170: 1088-1090.

Hem, J.D. 1985. Study and interpretation of chemical characteristics of natural waters. US Geological Survey Water Supply Paper 2254, pp. 120-157, $3^{\text {rd }}$ edition, US Govet. Printing Office, Alexandria, VA 22304, USA.
Khodapanah, L., Sulaiman, W.N.A., Khodapanah, N. 2009. Groundwater quality assessment for different purposes in Eshtehard District, Tehran, Iran. European Journal of Scientific Research, 36: 543553.

Kumar, M., Kumari, K., Ramanathan, A.L., Saxena, R. 2007. A comparative evaluation of groundwater suitability for irrigation and drinking purposes in two intensively cultivated districts of Punjab, India. Environmental Geology, 53: 553-574.

Lloyd, J.W., Heathcote, J.A. 1985. Natural Inorganic Hydrochemistry in Relation to Groundwater. 294 pp., Oxford University Press and Claredon Press, New York, USA.

Matheis, G. 1987. Nigeria rare metal pegmatites and their lithologic framework. Geological Journal, 22: 271-291.

McGowan, W. 2000. Water Processing, Residential, Commercial, Light-industrial, J. F. Harrison (ed.), 309 pp., $3^{\text {rd }}$ edition, Water Quality Association, Lisle, Illinois, USA.

Nosrat, A., Asghar, A.M. 2010. Assessment of groundwater quality and its suitability for drinking and agricultural uses in the Oshnavieh area, Northwest of Iran. Journal of Environmental Protection, 1: $30-40$.

Olayinka, A.I., Abimbola, A.F., Isibor, R.A., Rafiu, A.R. 1999. A geoelectrical hydrogeochemical investigation of shallow groundwater occurrence in Ibadan, southwestern Nigeria. Environmental Geology, 37: 31-39.

Omotoyinbo, O.S., Okafor, F.C. 2008. Influence of rock mineralogy on subsurface water in Ado-Ekiti, Nigeria. African Research Review, 2: 175-186.

Oyinloye, A.O., Ademilua, O.L. 2005. The nature of aquifer in the crystalline basement rocks of AdoEkiti, Igede-Ekiti and Igbara Odo areas, Southwestern Nigeria. Pakistan Journal of Scientific and Industrial Research, 48: 154-161.

Paliwal, K.V. 1972. Irrigation with Saline Water, Monogram-2 (New series), 198 pp., New Delhi, IAR1, India.

Piper, A.M. 1953. A graphic procedure in the geochemical interpretation of water analysis, $14 \mathrm{pp}$., US Geological Survey Ground-water Notes Geochemistry No. 12.

Piper, A.M. 1944. A graphic procedure in the geochemical interpretation of water analyses. American Geophysical Union Transaction, 25: 914-923.

Rajendra Prasad, D.S., Sadashivaiah, C., Rangnna, G. 
2009. Hydrochemical characteristics and evaluation of groundwater quality of Tumkur Amanikere lake watershed, karnataka, India. E-Journal of Chemistry, 6: 211-218. http://www.e-journals. net

Raju, N.J. 2007. Hydrogeochemical parameters for assessment of groundwater quality in the upper Gunjanaeru River basin, Cuddapah District, Andhra Pradesh, South India. Environmental Geology, 52: 1067-1074.

Richards, L.A. 1954. Diagnosis and Improvement of Saline Alkali Soils, 160 pp., United State Salinity Staff. Agriculture, Handbook 60, US Department of Agriculture, Washington DC, USA.

Sadashivaiah, C., Ramakrishnaiah, C.R., Ranganna, G. 2008. Hydrochemical analysis and evaluation of groundwater quality in Tumkur Taluk, Karnataka State, India. International Journal of Environmental Research and Public Health, 5: 158-174.

Saha, D., Dhar, Y.R., Sikdar, P.K. 2008. Geochemical evolution of groundwater in the Pleistocene aquifers of South Ganga plain, Bihar. Journal of the Geological Society of India, 71: 473-482.

Sawyer, G.N., McMcartly, D.L., Parkin, G.F. 2003. Chemistry for Environmental Engineering and Science, $752 \mathrm{pp} .5^{\text {th }}$ edition, McGraw Hill, New York, USA.

Singh, A.K., Mondal, G.C., Suresh, K., Singh, T.B., Tewary, B.K., Sinha, A. 2008. Major ion chemistry, weathering processes and water quality assessment in upper catchment of Damodar River basin, India. Environmental Geology, 54: 745-758.
SON. 2007. Nigerian Standards for Drinking Water Quality, 30 pp., Approved by Standard Organization of Nigeria (SON) Publ. NIS. 554.

Subramani, T., Elango, L., Damodarasamy, S.R. 2005. Groundwater quality and its suitability for drinking and agricultural use in Chithar River basin, Tamil Nadu, India. Environmental Geology, 47: 10991110.

Talabi, A.O., Tijani, M.N. 2011. Integrated remote sensing and GIS approach to groundwater potential assessment in the basement terrain of Ekiti area southwestern Nigeria. RMZ-Materials and Geoenvironment, 58: 303-328.

Tijani, M.N., Nton, M.E., Kitagawa, R. 2010. Textural and geochemical characteristics of Ajali Sandstone, Anambra Basin, SE Nigeria: Implication for its provenance. Comptes Rendus Geosciences, 342: 136-150.

Tijani, M.N. 1994. Hydrogeochemical assessment of groundwater in Moro area, Kwara State, Nigeria. Environmental Geology, 24: 194-202.

USDA 1954. Diagnosis and Improvement of Saline and Alkali Soils, Agricultural Handbook No. 60. pp. 1-160, Salinity Laboratory, US Department of Agriculture, USA.

WHO. 2004. Guidelines for Drinking Water Quality. 515 pp., Recommendations, vol. 1, $3^{\text {rd }}$ edition. WHO, Geneva, Switzerland.

Wilcox, L.V. 1955. Classification and Use of Irrigation Waters. Circular No. 696, 16 pp., United States Department of Agriculture, Washington DC, USA. 